\title{
"The Worst Place in the World for Women"
}

\section{Understanding the Causes of Conflict- Related Sexual Violence in the Democratic Republic of Congo: An Application of General Strain Theory}

\section{Coralie Gaia Niggeler}

MSc in International Crime, Conflict and Criminology, Vrije Universiteit Amsterdam

\begin{abstract}
This paper explores the nature of conflict-related sexual violence committed by the State Armed Forces (FARDC) in the Democratic Republic of Congo, through the application of the general strain theory. Findings show that sexual violence committed by the FARDC is commonly used as a form of personal catharsis and emotional release from perceived strains, as opposed to resulting from sexual desires or external institutional pressures. Further, the most influential contextual elements present in the local context of the FARDC, and which particularly encourage the propagation of sexual violence, include female FARDC soldiers receiving desired military positions, the centrality of strains to personal notions of masculinity and aspirations, the dismantling of social cohesion through patronage networks, and a lack of behavioural coping options. In turn, these factors reduce the efficiency of noncriminal coping strategies. Hence, interventions aimed at reducing the propagation of conflict-related sexual violence may benefit from more bottom-up and inductive approaches improving the individual circumstances of soldiers as opposed to solely focusing upon organisational change and military reform.
\end{abstract}

Keywords: conflict-related sexual violence, general strain theory, Democratic Republic of Congo, theoretical criminology, civil conflict 


\section{Introduction}

\section{"The Worst Place in the World for Women"}

The Democratic Republic of Congo (DRC) is deemed to be the "rape capital of the world," and "the worst place in the world for women." The origin of this claim stems from the armed conflict that erupted in the eastern territories of the DRC in 1998, which continues spreading unprecedented levels of violence and destruction to this day. ${ }^{2}$ In 2008 , conflictrelated deaths reached a high, with the war claiming approximately 45,000 lives per month. ${ }^{3}$ Conflict-related sexual violence (CRSV) was, and arguably still is, the most widely used weapon in the DRC. It is defined as "rape, sexual slavery, forced prostitution, forced pregnancy, forced abortion, enforced sterilization, forced marriage and any other form of sexual violence of comparable gravity [...] that is directly or indirectly linked to a conflict." 4 By approximations, CRSV has victimised a minimum of 200,000 women since the start of the armed conflict in the DRC. ${ }^{5}$ A significant proportion of this violence can be attributed to the State Armed Forces - Forces Armées de la République Démocratique du Congo (FARDC). ${ }^{6}$

This paper aims at furthering the understanding of FARDC sexual violence, by applying Agnew's general strain theory (GST) to narratives found in available academic sources. Although this theory - which will be defined and addressed further in the subsequent section - has not been used to explain CRSV in the past, its breadth and relevance make its application to CRSV a valuable new avenue of analysis. Further, it will enable the

\footnotetext{
${ }^{1}$ Jack Kahorha, "The Worst Places in the World for Women: Congo," The Guardian, June 14, 2011, https://www.theguardian.com/world/2011/jun/14/worst-places-in-the-world-for-women-congo.

${ }^{2}$ Kjeld van Wieringen, "To Counter the Rationality of Sexual Violence: Existing and Potential Policies Against the Genocidal Use of Rape as a Weapon of War in the Democratic Republic of Congo," Journal of International Humanitarian Action 5, no. 8 (2020), https://doi.org/10.1186/s41018-020-00074-4.

${ }^{3}$ Peter Moszynski, "5.4 Million People Have Died in the Democratic Republic of Congo Since 1998 Because of Conflict, Report Says," BMJ: British Medical Journal 336 (2008): 235, https://doi.org/10.1136/bmj.39475.524282.DB.

${ }^{4}$ United Nations Secretary-General, Conflict Related Sexual Violence: Report of the United Nations Secretary-General (United Nations, New York, March 29, 2019), 3. https://www.un.org/sexualviolenceinconflict/wp-content/uploads/2019/04/report/s-2019-280/Annual-report2018.pdf.

${ }^{5}$ Maria Eriksson Baaz and Maria Stern, Sexual violence as a Weapon of War?: Perceptions, Prescriptions, Problems in the Congo and Beyond (London: Zed Books, 2013), 45

${ }^{6}$ Maria Eriksson Baaz and Maria Stern, "Making Sense of Violence: Voices of Soldiers in the Congo (DRC)," The Journal of Modern African Studies 46, no. 1 (2008): 60, https://doi.org/10.1017/S0022278X07003072.
} 
contextualisation of CRSV, and assist the understanding of underlying motives that have potentially been overlooked in previous victim-oriented studies. Therefore, this paper seeks to answer the question: How can the causes of conflict-related sexual violence in the Congo (DRC) be understood in terms of Agnew's general strain theory?

Previous attempts at understanding the causes of CRSV have focused upon the exploration of victim testimonies and the framework of sexual violence as an institutionalised strategy. ${ }^{7}$ However, to comprehend the fundamental reasons driving CRSV, it is essential to incorporate the perspective of the perpetrators. In attempting to understand the perpetrators' perspective, this paper is in no way seeking to justify or excuse their actions, nor to discredit the victims' perspective. Rather, the idea is that in trying to address CRSV, it is of importance to understand what is driving those who commit it, as this is of necessity to effectively prevent and counter its future commission.

To constructively explore the drivers of CRSV, this paper will first provide further information on the theoretical framework, namely GST and its relevance in Section 2. This will be followed by Section 3 which will briefly explore the contextual background of the conflict in the DRC, particularly focusing upon conflict-related sexual violence. Finally, Section 4 will delve into the analysis by attempting to apply Agnew's theory to the context of CRSV in the DRC. This section will focus upon the identification of specific strains, complemented by Section 5 which will recognise the contextual characteristics of the conflict that increase the likelihood of strains resulting in CRSV. The paper will be concluded with a discussion of the analysis' implications for further academic research and policy, and a final summary.

\section{Theoretical Framework}

\subsection{Agnew's General Strain Theory}

The general strain theory argues that strains increase the perception of negative emotions, which in turn create internal tensions resulting in corrective actions, commonly

${ }^{7}$ Susan Bartels et al., "Militarized Sexual Violence in South Kivu, Democratic Republic of Congo," Journal of Interpersonal Violence 28, no. 2 (2013), https://doi.org/10.1177/0886260512454742; Anna Maedl, "Rape as a Weapon of War in the Eastern DRC?: The Victims' Perspective," Human Rights Quarterly 33, no. 1 (2011), https://doi.org/10.1353/hrq.2011.0005. 
crime. ${ }^{8}$ Agnew defines strain as "negative relationships with others: relationships in which the individual is not treated as he or she wants to be treated." 99 The three main types of strain refer to three different negative situations. Specifically, circumstances which actively "(1) prevent one from achieving positively valued goals [goal blockage], (2) present or threaten to present one with noxious or negative stimuli, (3) remove or threaten to remove positively valued stimuli [...]." 10 The first explains negative emotions and resulting deviance through a disjunction between aspirations and actual achievements. The second states that the presentation of negative stimuli may encourage deviance through an attempt at escaping, alleviating, managing, or seeking revenge for the presentation of said negative stimuli. Finally, the third may lead to deviance as the individual attempts to prevent, retrieve, or substitute these lost stimuli. ${ }^{11}$

In 2001, Agnew published a further paper in which he explored the contextual factors of strains that are most likely to cause said strains to result in criminal behaviour. He concluded that "strains are said to be most likely to result in crime when they (1) are seen as unjust, (2) are seen as high in magnitude, (3) are associated with low social control, and (4) create some pressure or incentive to engage in criminal coping." 12

When strains are perceived as unjust, they are more likely to provoke negative emotions which contribute to criminal behaviour, particularly anger, which tends to disrupt cognitive processes, obstructing non-criminal coping. ${ }^{13}$ In addition, a strain of higher magnitude is more difficult to cognitively minimise, meaning that non-criminal coping mechanisms tend to be less effective. ${ }^{14}$ When a strain is associated with low social control, it reduces the cost of crime for the individual, whilst also lessening the ability to cope in a non-criminal manner, due to a lack

\footnotetext{
${ }^{8}$ Robert Agnew, "Foundation for a General Strain Theory of Crime and Delinquency," Criminology 30, no. 1 (1992), https://doi.org/10.1111/j.1745-9125.1992.tb01093.x.

${ }^{9}$ Agnew, 48.

${ }^{10}$ Agnew, 50.

${ }_{11}$ Agnew.

12 Robert Agnew, "Building on the Foundation of General Strain Theory: Specifying the Types of Strain Most Likely to Lead to Crime and Delinquency," Journal of Research in Crime and Delinquency 38, no. 4 (2001): 319, https://doi.org/10.1177/0022427801038004001.

${ }^{13}$ Agnew.

${ }^{14}$ Agnew.
} 
of conventional commitments. ${ }^{15}$ Finally, strains particularly create pressure to engage in criminal coping when they are associated with other individuals who model criminal coping as the most effective way of dealing with said strain, ${ }^{16}$ substantiated through a lack of behavioural options.

\subsection{Relevance with Regards to Conflict Related Sexual Violence}

Although Agnew principally focused upon adolescent delinquency when developing GST, it remains a theory that can be extrapolated to different scenarios because of its breadth. ${ }^{17}$ This is particularly the case because Agnew sought to develop a general strain theory that built upon the limitations of previous strain theories, particularly Merton's theory of social strain. Merton's theory posits that strain results from a lack of alignment between socially accepted aspirations (i.e. The American Dream) and the means available to people to achieve these objectives. ${ }^{18}$ Hence, its application remains very limited as it primarily focuses upon lowerclass delinquency, whilst solely emphasising social stratification as a barrier to achieving goals. In addition, it is unable to explain why some individuals who experience strain do not turn to criminal activities as coping measures. ${ }^{19}$

Contrastingly, Agnew introduces the aforementioned three strain categories in order to explain individual differences. Hence, said categories are applicable to a vast array of individuals, irrespective of their social, economic, or cultural background. Additionally, the general strain theory's acknowledgment of the multitude of factors that may contribute to crime enables it to be closely related to other theories of crime. ${ }^{20}$ Particularly it addresses both cognitive and behavioural aspects that are conducive to crime, examples of the former would include the notion that negative emotions obstruct effective cognitive processing, whilst the latter can be found in the ideas pertaining to the social learning aspect of crime, addressed

\footnotetext{
${ }^{15}$ Agnew.

${ }^{16}$ Agnew. 193-194.

${ }^{17}$ Tim Newburn, Criminology: A Very Short Introduction (Oxford: Oxford University Press, 2018),

${ }^{18}$ Newburn.

${ }^{19}$ Newburn.

${ }^{20}$ Robert Agnew and Timothy Brezina, "General Strain Theory," in Handbook on Crime and Deviance, eds. Marvin D. Krohn, Nicole Hendrix, Gina Penly Hall, and Alan J. Lizotte (Cham: Springer, 2019).
} 
within the contextual factors of GST. ${ }^{21}$ The inclusion of other theories and perspectives enables GST to provide a holistic and complete approach to understanding the commission of crimes. Hence, GST remains one of the leading theories of crime and delinquency within the criminological field, ${ }^{22}$ thus its application in explaining CRSV seems undeniably rational.

\section{Congolese Civil Conflict}

\subsection{The Origins of War}

The ongoing conflict in the DRC originated in 1998, and is, as a result of the conflict's immersion in further African hostilities, referred to as “Africa's First World War", principally involving: the Rwandan genocide, the Ugandan, Angolan, and Sudanese civil wars. ${ }^{23}$ Following the Rwandan genocide in 1995, Hutus and Tutsis fled to eastern DRC which resulted in the formation of armed groups, and further opportunistic rebel groups. ${ }^{24}$ Rebel groups and third-party involvement in the conflict was fuelled by the DRC's extensive mineral wealth in the eastern part of the country. ${ }^{25}$ In 1998, Uganda and Rwanda began supporting these antigovernment rebel groups, which enabled them to control and exploit the resource rich areas. ${ }^{26}$ Their support was prompted as the DRC's president, Laurent Kabila, began dismissing highranking Rwandan officials in the DRC's government in 1998; despite Rwandan and Ugandan support during Laurent Kabila's coup against former president Mobutu Sese Seko in 1996. ${ }^{27}$ Hence, between 1998 and 2003, conflict broke out between the rebel groups, backed by Uganda and Rwandan forces, and government forces supported by Angola, Namibia, and Zimbabwe. ${ }^{28}$ The conflict over resources, the collapse of state functions, and wide-scale poverty contributed to the escalation of violence. ${ }^{29}$

\footnotetext{
${ }^{21}$ Agnew and Brezina.

${ }^{22}$ Nina Barbieri et al., "Assessing General Strain Theory and Measures of Victimization, 2002-2018," Aggression and Violent Behavior 49, (2019) Article 101304, https://doi.org/10.1016/j.avb.2019.06.005.

${ }^{23}$ Sara Meger, "Rape of the Congo: Understanding Sexual Violence in the Conflict in the Democratic Republic of Congo," Journal of Contemporary African Studies 28, no. 2 (2010): 124, https://doi.org/10.1080/02589001003736728.

${ }^{24}$ Council on Foreign Relations, "Violence in the Democratic Republic of Congo," last modified August 5, 2021, https://www.cfr.org/global-conflict-tracker/conflict/violence-democratic-republic-congo.

${ }^{25}$ Meger, "Rape of the Congo," 125.

${ }^{26}$ Meger.

${ }^{27}$ Meger.

${ }^{28}$ Council on Foreign Relations, "Violence in the Democratic Republic of Congo."

${ }^{29}$ Baaz and Stern, "Making Sense of Violence," 62.
} 
There have been various attempts at restoring peace within the $\mathrm{DRC}$, principally through a peace deal signed between the governments of Rwanda and the DRC in 2002 and the nationally-led establishment of a transitional government in $2003 .{ }^{30}$ However, conflict and violence between numerous militia groups remains widely present in the country, particularly in the eastern regions of Ituri and North and South Kivu, bordering Uganda and Rwanda. This can primarily be attributed to a lack of governance, weak institutions, and protracted corruption. $^{31}$

\subsection{Conflict-Related Sexual Violence in the DRC and the FARDC}

In times of war, CRSV is frequently perceived as an inevitable collateral damage, explained through the disruption of morals and societal norms.$^{32} \mathrm{CRSV}$ in the DRC is of an especially brutal nature, with acts being committed against girls as young as six months old. ${ }^{33}$

The study of sexual violence in the DRC is particularly puzzling because combatants openly acknowledge that the act of rape is immoral, in both military and non-military environments, however, they excuse it as a product of war. Prior to the outbreak of war, rape was seen as a grave crime. A former FARDC soldier who became a pastor after disarming stated, "God forbade this deed because the raped person is marked for the rest of her life," ${ }^{34}$ but the traditional system - and with it arguably traditional values - fell apart as the conflict progressed. ${ }^{35}$ Hence, this enabled perpetrators to deem their acts of sexual violence as exceptional, and attributable to the circumstances of war.

After the creation of a transitional government in June 2003, the FARDC was created through the process of brassage; the mixing of soldiers from the main rebel groups in order to

\footnotetext{
${ }^{30}$ Council on Foreign Relations, "Violence in the Democratic Republic of Congo."

${ }^{31}$ Council on Foreign Relations.

${ }^{32}$ Meger, "Rape of the Congo," 119.

${ }^{33}$ Michelle Nichols, "Babies as Young as Six Months Victims of Rape in War: U.N. Envoy,” Reuters,
} April 17, 2013, https://www.reuters.com/article/us-war-rape-un/babies-as-young-as-six-months-victims-of-rapein-war-u-n-envoy-idUSBRE93G13U20130417.

${ }^{34}$ Weapon of War, directed by Ilse van Velzen and Femke van Velzen, 2009. Amsterdam, IF Productions. https://www.idfa.nl/en/film/546ec94b-99d9-49eb-97b8-e3208567482b/weapon-of-war, 0:27:39.

${ }^{35}$ Maria Eriksson Baaz and Maria Stern, "Why Do Soldiers Rape? Masculinity, Violence, and Sexuality in the Armed Forces in the Congo (DRC)," International Studies Quarterly 53, no. 2 (2009), https://www.jstor.org/stable/27735106. 
form new brigades. ${ }^{36}$ This mixing of rebel groups, along with the fact that by 2009 the FARDC comprised an estimated 60,000 combatants, aggravated issues of control, regular pay, discipline etc. leading to a recurrent abuse of power. ${ }^{37}$ According to The United Nations Organization Mission in the Democratic Republic of Congo (MONUC), the FARDC accounted for $40 \%$ of the sexual violence committed in the DRC in the first six months of $2007 .{ }^{38} \mathrm{In}$ addition, there have been a series of events reflecting the widespread involvement of the FARDC in CRSV, notably, the conviction and imprisonment of Lt. Col. Kibibi Mutware of the FARDC, in 2011, for instigating mass rape, and a 2014 landmark case where 30 members of the FARDC were tried for committing rape. ${ }^{39}$

Finally, the FARDC did not predominantly use rape as a strategic tool, and none of the soldiers reported being ordered to rape or abduct individuals. ${ }^{40}$ This makes the FARDC an interesting case study as the removal of a coercive external order, originating from a political or military institution, may mean that motives to rape are inherently more personal. ${ }^{41}$ This allows the study of how a conflict environment may create internal pressures and strains.

\section{Identifying Strains}

General strain theory centres upon the notion that strains increase the perception of negative emotions, which create internal tensions commonly resulting in delinquency. ${ }^{42}$ Members of the FARDC have extensively described such sentiments. In order to understand the effect of strains on the individual, and whether they promote deviance (i.e. sexual violence), this section will align them with each of Agnew's aforementioned classes of strain.

36 "Soldiers Who Rape, Commanders Who Condone: Sexual Violence and Military Reform in the Democratic Republic of Congo,” Human Rights Watch, July 16, 2009,

https://www.hrw.org/report/2009/07/16/soldiers-who-rape-commanders-who-condone/sexual-violence-andmilitary-reform.

${ }^{37}$ Human Rights Watch, "Soldiers Who Rape, Commanders Who Condone."

${ }^{38}$ MONUC, “DR Congo: Monthly Human Rights Assessment - Nov 2007," Relief Web, January 21, 2008, https://reliefweb.int/report/democratic-republic-congo/dr-congo-monthly-human-rights-assessment-nov2007.

${ }^{39}$ Stacy Banwell, "Conflict Related Sexual Violence in the DRC," in Gender and the Violence(s) of War and Armed Conflict: More Dangerous to be a Woman?, ed. Stacy Banwell (Bingley, UK: Emerald Publishing Limited, 2020), 50.

${ }^{40}$ Gerald Schneider, Lilli Banholzer, and Laura Albarracin, "Ordered Rape: A Principal-Agent Analysis of Wartime Sexual Violence in the DR Congo," Violence Against Women 21, no. 11 (2015): 1353, https://doi.org/10.1177/1077801215593645.

${ }^{41}$ Schneider, Banholzer and Albarracin, "Ordered Rape."

42 Agnew, "Foundation for General Strain Theory." 


\subsection{Failure to Achieve Positively Valued Stimuli}

The failure of achieving positively valued stimuli causes a separation between ambitions and reality, causing internal tensions which may result in deviance. ${ }^{43}$

\subsubsection{The Règlement Militaire (RM)}

In the FARDC, the Règlement Militaire - military rules prescribing guidelines to which FARDC members are expected to adhere - play an important role in regulating the behaviour of soldiers, and ascribe what is perceived as proper conduct. Under the RM, the ideal soldier is described as being dignified, disciplined, educated, and a protector of the nation. ${ }^{44}$ FARDC members explicitly described the prohibition of sexual violence under the RM. A sublieutenant noted; “in the Règlement Militaire [...] we are not supposed to take people's women. That is bad." 45

However, grievances shared by FARDC soldiers include poverty, hunger, and lack of medical care, brought on as a result of abandonment from their superiors. Soldiers explained; "there are no bad soldiers. It is our leaders who are bad." 46 "We fought for them but weren't paid. That's why we asked the population for food so we could survive," ${ }^{47}$ explained another soldier. This lack of support eventually forced the soldiers to get involved in activities that fundamentally contradicted RM in order to survive and provide for their families. This included stealing from civilians and collecting illegal taxes. ${ }^{48}$

Countering the notions of RM failed to create a positively valued stimulus for the members of the FARDC. The respected image of an ideal soldier, adhering to RM, remained out of reach. In turn, the soldiers began experiencing negative feelings and adopted aggressive coping mechanisms. "[W]e smoked weed, we beat people, we raped, we did lots of bad things. We were like animals," 49 are some of the accounts of the soldiers. Others had this to say about their acts: "why do we commit rapes? Poverty and suffering" ${ }^{50}$ Since the idea of a perfect

\footnotetext{
${ }^{43}$ Agnew.

${ }^{44}$ Baaz and Stern, "Making Sense of Violence," 74.

${ }^{45}$ Baaz and Stern, 75.

${ }^{46}$ Baaz and Stern, 77.

${ }^{47}$ Weapon of War, 0:07:27.

${ }^{48}$ Baaz and Stern, "Making Sense of Violence," 76.

${ }^{49}$ Weapon of War, 0:05:55.

${ }^{50}$ Baaz and Stern, "Making Sense of Violence," 77.
} 
soldier under RM was unattainable, the soldiers arguably may have felt an urge to contradict the very foundations of what it stood for. The most straightforward way was to attack those that should be protected under RM, the civil society, with women and girls being the easiest targets. The ensuing sexual violence, committed as a form of catharsis, resulted in severely damaged consciences. Accounts such as "I did a lot of bad things, I raped girls and women. I'm suffering from my conscience" abound. ${ }^{51}$ Whilst by no means excusing such actions, this perspective substantiates the idea of coping with external driving factors (strains) as opposed to intrinsic desires.

In turn, this aggression caused civil society to rapidly replace the respect and admiration, previously felt for the armed forces, with fear and disrespect. In the words of some soldiers, "they [the civilians] do not understand. They no longer respect us. They see us as useless people [...]. Of course, they also fear us because of some of the bad things people in uniforms do." ${ }^{52}$ Protecting a civil society which respected and honoured their armed forces was a substantial element under RM. This meant that the ensuing civil disrespect highlighted the failure of the soldiers to attain the RM ideals.

\subsubsection{Men's Role as Providers}

The dominant ideal of masculinity in the DRC relies heavily on the notion of men being providers. ${ }^{53}$ Providing for families was perceived as being necessary to keep their wives faithful. ${ }^{54}$ However, poverty prevented soldiers from achieving this positively valued stimulus. The ensuing negative sentiments triggered CRSV which temporarily enhanced their dominance and heterosexuality, and also fulfilled their image of providers ${ }^{55}$ Hence, this form of sexual violence was a display of power, ${ }^{56}$ triggered by feelings of anger and failure, specifically a failure of achieving the role of a provider, as opposed to purely sexual desires.

\footnotetext{
${ }^{51}$ Weapon of War, 0:41:50.

52 Baaz and Stern, "Making Sense of Violence," 74.

${ }^{53}$ Hanno Brankamp, "Hegemonic Masculinity, Victimhood and Male Bodies as 'Battlefields' in Eastern DR Congo," Student Journal of International Relations 2015 2, no. 1 (2015).

${ }^{54}$ Meger, "Rape of the Congo," 128.

55 Baaz and Stern, "Why Do Soldiers Rape?" 505-508.

${ }^{56}$ Brankamp, "Hegemonic Masculinity."
} 


\subsection{Presence of Negative Stimuli}

Negative stimuli encourage deviance as it can be used as an outlet to escape or manage the negative emotions associated with said stimuli. ${ }^{57}$

\subsubsection{Poverty, Suffering, and Lack of Acknowledgment}

The presence of negative stimuli largely coincides with the failure of achieving positively valued stimuli, as they tend to prevent the latter from occurring. They also have a direct effect on the propagation of CRSV. Due to the lack of acknowledgment and appreciation from superiors, FARDC soldiers began viewing the conquering of villages and the ensuing rape and plunder as their reward. According to them, "when you arrive in a village and conquer it, everything you find is yours. The women, the goods, everything is yours." ${ }^{58}$ Arguably, they commit rape due to its severe consequences and repercussions on the society, allowing them to get rid of their negative stimuli through the destruction of something else. ${ }^{59}$ It could be inferred that soldiers found it to be the "best" way of expressing frustrations with the system, and also a way of gaining attention, irrespective of its positive or negative connotations.

Furthermore, in the army, both female and male soldiers noted the close interconnection between sexuality and money. One corporal stated; "sex and money go hand in hand. If you have no money, you will have no sex." ${ }^{60}$ Hence, the presence of the negative stimuli of poverty and suffering also pushed soldiers towards sexual violence, in order to deal with the resulting lack of legitimate sexual opportunities. In the words of a FARDC lieutenant colonel, "a soldier needs a bit of money [in] his pocket, and he needs to have leave. If that would happen it would reduce the rapes a lot." ${ }^{61}$ Sadly, conflict also pushes more women towards transactional sex, as their husbands are conscripted, and they are left primarily in charge of the family income. ${ }^{62}$ Hence, in this circumstance, CRSV finds itself in a spiral of ongoing violence. Conflict creates

\footnotetext{
${ }^{57}$ Agnew, "Foundation for General Strain Theory."

${ }^{58}$ Weapon of War, 0:24:39.

${ }^{59}$ Birthe Steiner et al., "Sexual Violence in the Protracted Conflict of the DRC Programming for Rape Survivors in South Kivu," Conflict and Health 3, no. 3 (2009), https://doi.org/10.1186/1752-1505-3-3.

${ }^{60}$ Baaz and Stern, "Why Do Soldiers Rape?" 510.

${ }^{61}$ Baaz and Stern, 509.

${ }^{62}$ Beth Maclin et al., “'They Have Embraced a Different Behaviour': Transactional Sex and Family Dynamics in Eastern Congo's Conflict," Culture, Health \& Sexuality 17, no. 1 (2015), https://doi.org/10.1080/13691058.2014.951395.
} 
poverty-stricken soldiers, whilst also forcing women to use sex as a commodity, creating the very division that encourages CRSV.

\subsubsection{Female Soldiers}

Female soldiers were common in the FARDC, however their presence was seen as being corrosive of fragile militarised masculinities. ${ }^{63}$ Thus, female military involvement may also be classified as the presence of a negative stimulus. The presence of women feminised the militarised sphere hence, the soldiers needed to adjust to female presence whilst avoiding the destruction of masculinity upon which the army was founded. ${ }^{64}$ This was often done by viewing women as "a temporary intruder who serves as an outlet or receptacle for male sexual lust." 65 This is a direct example of how sexual violence was being used to cope with a negative stimulus. However, this coping mechanism was particularly damaging as the internal sexual violence committed amidst the armed forces facilitated the spill-over towards sexual violence being committed against the civil society. More disturbing is the fact that the portrayal of women as a receptacle for male sexual desire was also internalised by the female soldiers present in the FARDC ranks, particularly in reference to the CRSV committed against civilian women. ${ }^{66}$ This shows the degree to which the perspective of women as negative stimuli - that need to be weakened through the use of violence - was spread and internalised within the armed forces.

\subsection{Removal of Positively Valued Stimuli}

The removal of positively valued stimuli may trigger deviance as an attempt to replace or recover said stimulus. ${ }^{67}$

\subsubsection{Loss of Superiority Towards Wives}

In the DRC women's sexuality is often portrayed as being motivated by economic needs. A FARDC male sergeant explained; “[when] I have no money to give for food she will get tired and when I am at work she will give her body to another man just to get a little

\footnotetext{
${ }^{63}$ Baaz and Stern, "Why Do Soldiers Rape?" 505-508.

${ }^{64}$ Baaz and Stern.

${ }^{65}$ Baaz and Stern, 507.

${ }^{66}$ Baaz and Stern, 509.

${ }^{67}$ Agnew, "Foundation for General Strain Theory."
} 
something to feed the children." ${ }^{68}$ Hence, if a man does not have the time or financial capabilities to provide and care for his family, as a result of being conscripted, it is commonly believed that their wives will no longer acknowledge their superiority. This comprises the removal of a positively valued stimulus. Therefore, with reference to the general strain theory, ${ }^{69}$ the complete or anticipated removal of their wife's respect may explain sexual violence as a way of coping with this lost stimulus. The idea of coercing or retrieving lost respect or physical affection through violence was not uncommon.

\section{Contextual Elements of Strains}

Agnew ${ }^{70}$ explored contextual elements of strains that particularly encourage criminal behaviour (i.e., sexual violence). This section will explore whether said contextual factors are described in FARDC narratives, in order to analyse whether the context in the DRC is particularly conducive to CRSV.

\subsection{Perceived as Unjust}

In terms of the FARDC, most of the soldiers shared a belief that a successful soldier (according to RM), was "an educated soldier who does administrative work, works in the military courts [...] not the tough, brave soldier fighting at the front line." ${ }^{\prime 11}$ Many FARDC members did not join the army to engage in violence but rather as a last resort. It can be inferred that their perspective of masculinity holds Western influences; "a wealthy urban man who works in an office, owns a luxurious house and a nice car." 72

Intensifying this strain is the fact that the aforementioned desirable positions are administered to the female soldiers in the FARDC. A male corporal noted thus; "our superiors say that they are fair - that is equality. But they are not. They give the women all the good jobs. [...] If you look at the administrative jobs - it is only women!" 73 In their perspective, this aggravates the discord between their status as soldiers and their view of an ideal solider. The strain is seen as unfair, and increases the general hostility felt towards women. This has the

\footnotetext{
${ }^{68}$ Baaz and Stern, "Why Do Soldiers Rape?" 507.

${ }^{69}$ Agnew, "Foundation for General Strain Theory."

${ }^{70}$ Agnew, "Building on the Foundation."

${ }^{71}$ Baaz and Stern, "Making Sense of Violence," 70.

72 Baaz and Stern, 71.

${ }^{73}$ Baaz and Stern, 72.
} 
potential of increasing CRSV as individuals are less likely to perceive guilt when they believe that the injustice they face warrants the crime they commit.

\subsection{High in Magnitude}

Despite the magnitude of a strain being perceived subjectively, there are some measures that can be applied in an attempt at understanding its degree. These are the centrality, currency, and frequency of the strain. ${ }^{74}$ All of the strains mentioned in Section 4 are of a long-term nature, and were present during the entirety of the soldiers' career in the FARDC. The strains were central to the soldiers as they threatened their core masculine and aspirational values. Hence, it can be inferred that the subjective strains felt by the soldiers were of an intense and invasive nature.

\subsection{Associated with Low Social Control}

The FARDC soldiers have been distanced from familial and social ties in two ways: due to the indirect result of the aforementioned strains, or, more generally, as a common consequence of joining the armed forces. Furthermore, the patronage networks in the FARDC severely undermine cohesion and bonding between peers and commanders. This is due to the fact that patrons differ in power (services in the FARDC are heavily dependent upon negotiations), meaning that some colleagues in the same unit can be more well off compared to others. ${ }^{75}$ As a former member of the FARDC stated, "it hurts me to see my comrades get paid well and not me." ${ }^{76}$ Hence, soldiers find themselves in environments with low social control, whilst simultaneously being indoctrinated into a militarised environment in which sexual violence plays a dominant role in the overarching discourse - particularly, the conception of an ideal soldier and the inability of the soldiers to adhere to such an image as discussed previously.

\footnotetext{
${ }^{74}$ Agnew, "Building on the Foundation," 332-335.

75 Judith Verweijen, "Soldiers Without an Army? Patronage Networks and Cohesion in the Armed Forces of the DR Congo,” Armed Forces \& Society 44, no. 4 (2018), https://doi.org/10.1177/0095327X17740096.

${ }^{76}$ Weapon of War, 0:46:30.
} 


\subsection{Lack of Behavioural Options Incentivising Criminal Coping}

Strains tend to incentivise criminal coping when subcultural beliefs define the strain as unjust and high in magnitude. ${ }^{77}$ Hence, this contextual element tends to be embedded in the aforementioned ones, and is, to an extent, already satisfied. Additionally, a strain particularly incentivises criminal coping in the context of a lack, or complete absence of other behavioural options. This is illustrated within the narrative of various FARDC soldiers, as they do not qualify their violence as normal, as quoted from a former soldier: "my Captain, please do your best to make me a civilian again," 78 but still engage in it to challenge the idolised image of the soldier they cannot attain. From this, it may be deduced that their limited behavioural options of either accepting their predicament or rebelling against it (with the former becoming less bearable as strains become more intense) may account for incentivising this criminal behaviour. In addition to this, criminal coping is imitated and reinforced by fellow soldiers.

\section{Discussion}

\subsection{Methodological Limitations}

As mentioned in Section 2, GST was initially developed to explore teenage delinquency. Hence, the strain categories may not fully encompass those experienced in times of conflict. Some elements cannot be applied to said categories without extreme interpretations, especially because they focus primarily on inter-personal relations, which often disregards the macro- and meso-level influences of war. In addition, GST does explain deviance, however it is not specific to sexual violence, hence it may be believed that this analysis distorts the essence of the theory, making it less reliable. Therefore, it may be beneficial to apply a further theory alongside Agnew's, to expand the scope of analysis.

Finally, the findings of this analysis may be difficult to generalise seeing as CRSV is strongly dependent upon local, cultural, and societal perceptions.

With these limitations in mind, the paper will now proceed to the policy and theoretical implications of its analysis.

\footnotetext{
77 Agnew, "Building on the Foundation."

${ }^{78}$ Weapon of War, 0:46:23.
} 


\subsection{Policy and Theoretical Implications}

Conflict-related sexual violence does not occur in a vacuum. Instead, it is the result of the confluence of personal, relational, and societal circumstances. This is important to note because personal circumstances seem to have been neglected in past policies which principally aimed at institutionalising changes. Although adopting a more individually-focused perspective may provide for viable approaches to the effective reduction of CRSV, it is essential to reiterate that in doing so, this paper is in no way diminishing the experience of the victims, and by no means excusing the acts committed by the perpetrators.

In order to target personal circumstances, it would be beneficial to complement the already established top-down interventions focusing on organisational change and military reform, ${ }^{79}$ with a bottom-up and inductive approach improving the individual circumstances of soldiers. Said circumstances may have the potential of reducing the impact of external relational and societal effects, which are both more difficult to control and account for, and from where strains tend to originate.

Granting soldiers access to psychological support may be fruitful as it will provide them with an alternate method of emotional release, in turn reducing the propagation of CRSV; especially as this is associated with a higher cost. This is apparent in the long-term psychological impact that the sexual violation had on the conscience of FARDC soldiers. Furthermore, the establishment of discussion forums may be beneficial, as open discussion may aid reflection, resulting in behavioural changes. This could lessen the number of individuals committing CRSV to cope with their frustrations.

Finally, it is important to attempt to understand why CRSV in the DRC is of a particularly brutal nature. Exploring this poses challenges and warrants extensive research, as the source of the brutality could be found in, arguably, all levels of society, including in the personal dispositions of individuals, inter-personal influences, publicly held beliefs on gender

\footnotetext{
${ }^{79}$ Anette B. Houge and Kjersti Lohne, "End Impunity! Reducing Conflict-Related Sexual Violence to a Problem of Law," Law \& Society Review 51, no. 4 (2017), https://doi.org/10.1111/lasr.12294; Louise Olsson et al., "Peacekeeping Prevention: Strengthening Efforts to Preempt Conflict-Related Sexual Violence," International Peacekeeping 27, no. 4 (2020), https://doi.org/10.1080/13533312.2020.1782752.
} 
relations, etc. However, the contextual elements increasing strain intensity and thus ensuing violence, mentioned in Section 6, may be a viable starting point, as FARDC members have extensively described scenarios that line up with Agnew's contextual categories. In turn, this may increase the importance of adopting a broad multi-level intervention, in order to target contextual factors that may arguably account for the inherent cruelty of CRSV. However, further investigation will be necessary to, not only list possible contextual elements, but also discern which ones are the most influential, and thus should take precedence in interventions.

\section{Conclusion}

\subsection{Cathartic Properties of Conflict-Related Sexual Violence}

This paper used GST to understand, but under no circumstances excuse, the causes of CRSV committed by the FARDC in the Congo (DRC). The application of GST facilitated the categorisation of the factors facilitating CRSV, and their independent relation to sexual violence. This study concluded that sexual violence was committed as a result of a variety of strains. Particularly, this paper analysed the failure of achieving positively valued stimuli (RM, and the male role of providers), the presence of negative stimuli (poverty, suffering, a lack of acknowledgment, and female FARDC soldiers), and the removal of positively valued stimuli (superiority towards wives). Hence, it may be inferred that sexual violence may commonly be used as a form of personal catharsis and emotional release from strains, as opposed to solely resulting from sexual desires, or external institutional pressures, particularly the notion of rape being used as a weapon of war.

The comprehension of internal motives and strains was substantiated by the identification of contextual elements that enforced said strains and thus ensuing CRSV. These included, female FARDC soldiers receiving desired military positions, the centrality of strains to personal notions of masculinity and aspirations, the dismantling of social cohesion by patronage networks, and a lack of behavioural options, incentivising criminal coping. The presence of these contextual elements meant that strains would become more intense, reducing the efficiency and ability of non-criminal coping for FARDC members. 


\section{Bibliography}

Agnew, Robert. "Building on the Foundation of General Strain Theory: Specifying the Types of Strain Most Likely to Lead to Crime and Delinquency." Journal of Research in Crime and Delinquency 38, no. 4 (2001): 319-361. https://doi.org/10.1177/0022427801038004001.

_ "Foundation for a General Strain Theory of Crime and Delinquency." Criminology 30, no. 1 (1992): 47-88. https://doi.org/10.1111/j.1745-9125.1992.tb01093.x.

Agnew, Robert, and Timothy Brezina. "General Strain Theory." In Handbook on Crime and Deviance, edited by Marvin D. Khron, Nicole Hendrix, Gina Penly Hall, and Alan J. Lizotte, 145-160. Cham: Springer, 2019.

Baaz, Maria Eriksson, and Maria Stern. "Making Sense of Violence: Voices of Soldiers in the Congo (DRC).” The Journal of Modern African Studies 46, no.1 (2008): 57-86. https://doi.org/10.1017/S0022278X07003072.

. "Why Do Soldiers Rape? Masculinity, Violence, and Sexuality in the Armed Forces in the Congo (DRC)." International Studies Quarterly 53, no. 2 (2009): 495-518. http://www.jstor.org/stable/27735106.

- Sexual Violence as a Weapon of War?: Perceptions, Prescriptions, Problems in the Congo and Beyond. London: Zed Books, 2013.

Banwell, Stacy. "Conflict Related Sexual Violence in the DRC." in Gender and the Violence(s) of War and Armed Conflict: More Dangerous to be a Woman?, edited by Stacy Banwell, 43-63. Bingley, UK: Emerald Publishing Limited, 2020.

Barbieri, Nina, Stephen J. Clipper, Chelsey Narvey, Amanda Rude, Jessica M. Craig, and Nicole Leeper Piquero. "Assessing General Strain Theory and Measures of Victimization, 2002-2018." Aggression and Violent Behavior 49 (2019) Article 101304. https://doi.org/10.1016/j.avb.2019.06.005.

Bartels, Susan, Jocelyn Kelly, Jennifer Scott, Jennifer Leaning, Denis Mukwege, Nina Joyce, and Michael VanRooyen. "Militarized Sexual Violence in South Kivu, Democratic Republic of Congo.” Journal of Interpersonal Violence 28, no. 2 (2013): 340-358. https://doi.org/10.1177/0886260512454742.

Brankamp, Hanno. "Hegemonic Masculinity, Victimhood and Male Bodies as 'Battlefields' in Eastern DR Congo.” Student Journal of International Relations 2, no. 1 (2015): 528.

Council on Foreign Relations. "Violence in the Democratic Republic of Congo." Last modified August 5, 2021. https://www.cfr.org/global-conflicttracker/conflict/violence-democratic-republic-congo. 
Houge, Anette Bringedal, and Kjersti Lohne. "End Impunity! Reducing Conflict-Related Sexual Violence to a Problem of Law." Law \& Society Review 51, no. 4 (2017): 755789. https://doi.org/10.1111/lasr.12294.

Kahorha, Jack. "The Worst Places in the World for Women: Congo.” The Guardian, June 14, 2011. https://www.theguardian.com/world/2011/jun/14/worst-places-in-the-worldfor-women-congo.

Maclin, Beth, Jocelyn Kelly, Justin Kabanga, and Michael VanRooyen. "“They Have Embraced a Different Behaviour': Transactional Sex and Family Dynamics in Eastern Congo's Conflict." Culture, Health \& Sexuality 17, no. 1 (2015): 119-131. https://doi.org/10.1080/13691058.2014.951395.

Maedl, Anna. "Rape as Weapon of War in the Eastern DRC?: The Victims' Perspective." Human Rights Quarterly 33, no. 1 (2011): 128-147. https://doi.org/10.1353/hrq.2011.0005.

Meger, Sara. "Rape of the Congo: Understanding Sexual Violence in the Conflict in the Democratic Republic of Congo.” Journal of Contemporary African Studies 28, no. 2 (2010): 119-135. https://doi.org/10.1080/02589001003736728.

MONUC. "DR Congo: Monthly Human Rights Assessment - Nov 2007.” Relief Web. January 21, 2008. https://reliefweb.int/report/democratic-republic-congo/dr-congomonthly-human-rights-assessment-nov-2007.

Moszynski, Peter. "5.4 Million People Have Died in Democratic Republic of Congo Since 1998 Because of Conflict, Report Says.” BMJ: British Medical Journal 336 (2008): 235. https://doi.org/10.1136/bmj.39475.524282.DB.

Newburn, Tim. Criminology: A Very Short Introduction. Oxford: Oxford University Press, 2018.

Nichols, Michelle. "Babies as Young as Six Months Victims of Rape in War: U.N. Envoy." Reuters, April 17, 2013. https://www.reuters.com/article/us-war-rape-un/babies-asyoung-as-six-months-victims-of-rape-in-war-u-n-envoy-idUSBRE93G13U20130417.

Olsson, Louise, Angela Muvumba Sellström, Stephen Moncrief, Elisabeth Jean Wood, Karin Johansson, Walter Lotze, Chiara Ruffa, Amelia Hoover Green, Ann Kristin Sjöberg, and Roudabeh Kishi. "Peacekeeping Prevention: Strengthening Efforts to Preempt Conflict-Related Sexual Violence.” International Peacekeeping 27, no. 4 (2020): 517585. https://doi.org/10.1080/13533312.2020.1782752.

Schneider, Gerald, Lilli Banholzer, and Laura Albarracin. “Ordered Rape: A Principal-Agent Analysis of Wartime Sexual Violence in the DR Congo." Violence Against Women 21, no. 11 (2015): 1341-1363. https://doi.org/10.1177/1077801215593645. 
"Soldiers Who Rape, Commanders Who Condone: Sexual Violence and Military Reform in the Democratic Republic of Congo.” Human Rights Watch. July 16, 2009. https://www.hrw.org/report/2009/07/16/soldiers-who-rape-commanders-whocondone/sexual-violence-and-military-reform.

Steiner, Birthe, Marie T. Benner, Egbert Sondorp, K. Peter Schmitz, Ursula Mesmer, and Sandrine Rosenberger. "Sexual Violence in the Protracted Conflict of DRC Programming for Rape Survivors in South Kivu." Conflict and Health 3, no. 3 (2009): 1-9. https://doi.org/10.1186/1752-1505-3-3.

United Nations Secretary-General. Conflict Related Sexual Violence: Report of the United Nations Secretary-General. United Nations, New York, March 29, 2019. https://www.un.org/sexualviolenceinconflict/wp-content/uploads/2019/04/report/s2019-280/Annual-report-2018.pdf.

van Velzen, Ilse, and Femke van Velzen, dirs. Weapon of War, 2009: 59min. Amsterdam: IF Productions. https://www.idfa.nl/en/film/546ec94b-99d9-49eb-97b8e3208567482b/weapon-of-war.

van Wieringen, Kjeld. "To Counter the Rationality of Sexual Violence: Existing and Potential Policies Against the Genocidal Use of Rape as a Weapon of War in the Democratic Republic of Congo." Journal of International Humanitarian Action 5, no. 8 (2020): 1-14. https://doi.org/10.1186/s41018-020-00074-4.

Verweijen, Judith. "Soldiers Without an Army? Patronage Networks and Cohesion in the Armed Forces of the DR Congo." Armed Forces \& Society 44, no. 4 (2018): 626-646. https://doi.org/10.1177/0095327X17740096. 